\title{
Co-Creation of Public Services; Levels of Customers' Participation
}

\author{
Milda Damkuviene*, Evandzelina Petukiene \\ Business and Public Management Dept., Siauliai University, Siauliai, Lithuania \\ *Corresponding author email: m.damkuviene@gmail.com
}

Received: 06 March 2018 / Revised: 09 April 2018 / Accepted: 10 April 2018 / Published: 15 April 2018

\begin{abstract}
Customer participation is one of the critical research issues in service management. This study draws on the client participation concept to explore the content and levels of customer participation in public services (Lithuanian elderships). By integrating Unified Service theory, Service Dominant logic, and using a research design with 12 interviews and 600 participating customer surveys, the study confirms the three level customer participation model, identifies four categories of participating customers and shows how sociodemographic characteristics affect customer participation level. Data suggest that public service providers need to pay attention to customer participation management (identification, selection, education and motivation).
\end{abstract}

Keywords: community engagement and advocacy, customer participation, service co-creation, participation levels

\section{Introduction}

The idea of customer participation and value co-creation has spread rapidly in public sector over the past decade. The co-creation of value means "the joint creation of value by the company and the customer" (Prahalad \& Ramaswamy, 2004, p. 8). The traditional model of government is when a public entity receives funds through budgetary allocation. Those funds are used for developing and delivering services to citizens, who in turn only consume them. This traditional perspective is shifting its focus toward buman engagement perspective (Gouillart \& Hallett, 2015) with the dominant question, how service user participation can be "added into" the process of service planning and production to improve the quality of these services (Osborne et al., 2016, p. 5). In today's markets, customers have access to unlimited amounts of information, and advancements in technology have opened new doors of interaction with other customers and companies around the world. Development of ICT technologies is changing the ways and tools of communication between individuals, allowing them to share information and knowledge, which under the right circumstances can result in a collective action taking (Stembert, 2011). Active citizenship and active communities are treated as additional valuable resources, important for the planning and delivery of effective public services (Durose et al., 2013). In a co-creation, the role of service provider and a client overcome the well-defined boundaries, new modes of interaction and new forms of relationships are formed. In a co-creation process, a public sector entity opens its value chain to the stakeholders whom it serves (Gouillart \& Hallett, 2015). As a result, customers may become as co-producers who take over specific activities in the production chain (Prahalad \& Ramaswamy, 2000; Vargo \& Lusch, 2004) or as cocreators whose experiences with services and their participatory behaviour can be of added value to the organisation and the customer itself.

Research indicates that customers perceive greater benefits when involved in a relationship with a service (Kinard \& Capella, 2006). Customers are more satisfied with the quality of the services they receive (Bitner et al. 1997; Stembert, 2011). Customer participation augments customer perceived value and leads to 
stronger relationships (Kelley et al., 1990). Research shows that co-creation not only influences customer satisfaction and loyalty but also helps companies to achieve efficiency, effectiveness (Vooberg et al., 2015) and competitive advantage (Grissemann \& Stokburger-Sauer, 2012).

However, the level of customer involvement subject to personal characteristics (Claycomb et al., 2001), specifics of services, financial, social, technical, and psychological factors, varies. Some customers are more willing and able to engage meaningfully than others. Involvement requires monetary and nonmonetary customer resources: time, physical and psychological efforts which can be perceived as costs of participation (Hoyer et al., 2010). Relative to these costs, customers compare benefits they receive in such participatory experiences (Etgar 2008; O'Hern \& Rindfleisch 2009) and estimate the value of their participation. Different levels of customer participation have different perspectives, needs, and challenges. Having in mind that customer participation is essential for the effectiveness of public services and their successful development, understanding the levels of customer participation and their contents is of the strategic importance. The object of the research is the levels and content of participatory customer behaviour in public services. The aim of the research is to identify the characteristics and the levels of participatory customer behaviour in public services.

\section{Methods}

To determine the characteristics of participatory customer behavior, individual semi-structural expert interviews (N 12) were carried out. Twelve Lithuanian elders (the leaders/heads of Lithuanian elderships ${ }^{1}$,) in the service practice of whom, cases of the active participation of customers were identified. The sample units (elderships) were selected under the following criterion: 1) higher number of joint activities with citizens if compared to common situation in Lithuanian elderships; 2) higher number of NGOs, operating in elderships, if compared to common situation in Lithuania 3) activeness of the elder (social and professional activeness). The data were collected until the repetition appeared (the saturation point has been reached).

By the interview data, customer participation questionnaire was developed. The survey with participating customers $(\mathrm{N}=600)$ was undertaken to determine if the participatory behaviour characteristics fall under some structure, which defines the extent/level of customer participation and to define the effect of sociodemographic variables on customer participation level. Statistical data analysis was performed using SPSS software.

\section{From Participation to Value Co-creation}

Two perspectives - Unified Service theory (UST) (Sampson \& Froehle, 2006) and Service Dominant Logic (S-D logic) (Vargo \& Lusch 2004) help to understand and explain customer participation in the value creation process. The central premise of the UST is that "within service processes, the customer provides significant inputs into the production process" (Sampson \& Froehle, 2006, p. 331). UST thus understands a service process as a production process where the presence of customer inputs is a necessary condition. Its basic premise is that customer participation (as co-production) is an essential and inalienable core component of service delivery: you cannot have (public) service delivery without participation (Osborne et al., 2016). In S-D logic, customer input is thus central to define services (Grissemann \& Stokburger-Sauer, 2012). In the service-dominant perspective, the value is co-created through the transformation of service components at the point of co-production (Lusch \& Vargo 2006).

Co-creation is a new vision for public services which recognise the use of resources that citizens have for the advancement of services. Co-creation is described as a natural extension of the existent "crowd-sourcing" trend when groups of people outside the organisation give their time, ideas usually on a voluntary basis to

\footnotetext{
${ }^{1}$ eldership (lith. „seniūnija“) is the smallest administration division of Lithuania. An eldership could either be a very small region consisting of few villages, one single town, or part of a big city. Elderships vary in size and population. A few elderships make up a municipality. Elderships are administering services, offered for citizens in their territories (e.g. social services, establishments of children playground and etc.). Synonyms: townships, rural communities, wards.
} 
Damkuviene et al., Adv. J Social Sci.; Vol. 2 Issue 1, pp: 40-47, May 2018

solve some problem, to develop the product or even to create the new one. The approach is value-driven and built on the premise that those who are affected by a service (or are using the product) are the best designers of it.

The term co-creation refers to commitment and action which is required of both the parties involved (customer and organisation). Co-creation requires active efforts/inputs (cooperative behaviours) and decision making (John, 2003; Joshi \& Moore, 2004; Alford, 2009) where the common outcome is attained by fostering relationships, not only the transaction itself. It means that a participating customer demonstrates a particular attitude and behaviour (offers some of his resources), for service value co-creation process.

Service co-creation emerges when both stakeholders' efforts are evident (Bitner et al., 1997; Claycomb et al., 2001; Hsieh et al., 2004). They allow shaping the service customers receive as well as the quality that is achieved and to develop service in the future. Customers insert themselves into the public service value chain and become active participants in it (Gouillart \& Hallett, 2015). Sampson and Froehle (2006) highlight two basic types of customer inputs: the customer-self inputs (i.e., the employment of customer labour in the service development process) and customer provided information (i.e., the provision of information by the customer that is indispensable for the service delivery). It means that customers may become oral participants (i.e., offering help and advice to other customers) (Harris et al., 1995; Harris et al., 1999; Parker \& Ward, 2000), organizational consultants (i.e. making suggestions to the service provider) (Bitner et al., 1997) and promoters of the organization (i.e. spreading positive word of mouth about the organization). As a result, co-creation has the dual benefit (Gouillart \& Hallett, 2015) or practical outcomes (emotional, behavioural, physical and other changes) for both parts.

\section{Levels of Customer Participation}

Levels of customer participation are related to customers' ability, role clarity, and willingness to participate. It means that these factors influence how much customers participate and the amount of value-in-use that can be created (Rodie \& Kleine, 2000, Frank \& Rettinger, 2010). It is agreed that levels of the customers' participation differ according to the type of service and its environment (Claycomb et al., 2001). Scientists follow the typology of three levels of participation, recognised in the service marketing theory (Bitner et al., 1997). They could be described as low, moderate and high. Levels of participation range on a continuum from informing, consultation on an individual level including feedback about services, surveys, and complaints through participation in the planning, development, and innovation of services. Arnstein's (as cited in Kreiken, 2008) ladder of citizen participation which defines the extent of citizens' power in determining the end product. The ladder begins with the manipulation, "where citizens are involved only „on paper," i.e., certain "advisory groups" are set up to demonstrate that "real people" are involved in a project which is not even discussed with these people" (Kreiken, 2008, para. 2). The ladder ends with the citizen control level where citizens ,are in full charge of a policy or plan and that they are "able to negotiate the conditions under which "outsiders" may change them" (Kreiken, 2008, para. 9).

Service requiring a low level of customer participation will only need the customer's physical presence. Usually, it is highly standardised service (Bitner et al., 1997), and the input of customers can be the compliance to legal or social norms (Needham \& Carr, 2009). Here citizens only perform some implementation tasks and can be described as co-implementers of public services (Vooberg et al., 2015). If the service does not require the high contact, the passive participation can simply cover the omission of some appropriate harmful actions. There is empirical evidence that low participating customers, more often tend to have quality complaints (Yen et al., 2004).

Moderate participation level requires some inputs (cooperating behaviour) from customers, such as information, effort, and physical possessions (Bitner et al., 1997). The customer becomes the consultant of the organisation as well as the quality inspector and conveyor of information (positive and negative) for other potential and existing customers. Negative feedback, as well as positive feedback, is attributed to the cooperating behaviour as this customer input (information) is a good starting point for improvements. 
Because of cooperative customer behaviour, service providers can better customise and individualise services according to individual needs and priorities (Needham and Carr, 2009). In fact, the customer is expected to contribute to the service delivery and perform some of the tasks traditionally performed by the service employee. Moderate participation level requires a low level of use of the customers' efforts or resources (Arnould et al., 2006), does not expect customers to gain new skills, very often the initiative lies within the public organisation (Vooberg et al., 2015). There is a high risk of the failures when customers fail to perform their required tasks successfully (Etgar, 2008).

High participation represents the citizen as an initiator and the government as an actor that follows (Vooberg et al., 2015). High participation level is the state where the customer co-creates the service together with the service provider (Bitner et al., 1997; Claycomb et al., 2001; Hsieh et al., 2004). High participation increases the possibility of identification of problems and understanding of conditions, under which those difficulties appear (Mottiar \& White, 2003). The customer offers his time and other (usually mental) resources to design and improve the service, involves the partnership with the organisation. The cooperation quality partially affects the quality of the gained service (Yen et al., 2004) that can, in turn, lead to the transformation of services, influencing changes in the authority control as well as the development of new planning and management mechanisms (Needham \& Carr, 2009).

\section{Categories of Participating Customers: Results of the Expert Interview}

Experts (elders) were asked to describe and characterise the "involved," "active," "participating" customer of public services. Informants describe those who have involved as mature conscious citizens who care about personal as well as public welfare, actively participate in local community life, act for the benefit of society. They do not lack the social, civic consciousness, which is oriented towards designing future positive changes in the community and whole society. Actively participating customers are characterised as initiative, insightful, cooperating, those who generate ideas and deliver various inputs, they are often members of some local community, nongovernmental organisations.

It was found that as customers' participation behaviours vary, i.e., inputs, efforts, and cooperating behaviours differ. Four categories of participating customers were identified regarding the extent of customer input and contribution.

Category 1- "proactive." Clients that offer solutions and contribute when implementing them;

Category 2- "silent supporters." Clients that have positive attitude towards participation, but are reserved in taking actions (they are positively thinking, discussing contributions, but they are not sure about the right ways, - so they stay reserved);

Category 3- "self-interested." Clients that make some contributions (show some effort) when personal benefits are evident.

Category 4- "demanders." Clients that demand, require and insist ("I am requiring and asking, I have a right to do so because I pay taxes").

The first category of clients ("proactive") usually come with particular suggestions; they are aware of what they want and how their offering should be realised. They have many ideas of how to improve services, have suggestions how to do it at the lowest possible costs and can explain the benefits of the implemented suggestion.

The second category ("silent supporters") often lacking knowledge about the realisation of their ideas. They share their thoughts and seek for the support to realise them. These persons contribute by individual inputs when they have the knowledge and needed skills for implementation of their plans.

The third category - "self-interested." They have a positive attitude towards the participation; they tend to join. However they are not the initiators or idea generators, yet they enter activities when personal benefits are evident. It is the part of customers, performing the role of supporters when personally invited and encouraged to participate.

The fourth category - "demanders." These customers are not concerned about public wealth but are greatly demanding. They are usually dissatisfied with the eldership services, openly express their dissatisfaction. 
Damkuviene et al., Adv. J Social Sci.; Vol. 2 Issue 1, pp: 40-47, May 2018

Their' efforts are often focused on claiming, seeking "the truth," registering the evidence of dissatisfaction. However, they are usually not able to provide suggestions or enter a constructive dialogue.

\section{Levels of Customer Participation: Results of the Survey with Participating Customers}

On the base of the qualitative research, the scale of client participation was formed. The reliability and validity of the scale were assessed using exploratory and confirmatory factor analyses. To identify characteristics of the actively participating customer, the attribution of separate research units to some appropriate level of participation was performed. First, exploratory analysis (Principle components) was conducted to identify the number of dimensions of the scale. Results of the factor analysis are the base for the introduction of a new variable, expressing the activeness of customer participation in public services. The defined factor weights were applied in the calculation of the values of the new variable. The factor, called "Participation activeness" is the higher level variable, which is composed of lower level factors with their factor weights.

Three-factor customer participation activeness scale was extracted. The composed $\mathrm{Z}$ scale corresponds to the low, medium, high levels of client participation. Weights, obtained by the method of factor analysis, retaining factor values by the method of regression, correspond to the three-level customer participation model. Statements, attributed to the highest level of the customers' participation, have the highest weight identified; while those assigned to the lowest level, have the lowest weight determined (see Table 1).

Table 1: Participation Activeness (Factor Analysis, $n=600$ )

\begin{tabular}{|c|c|}
\hline Factors (F1, F2, F3) / Items & Factor load \\
\hline \multicolumn{2}{|l|}{ High level of participation (F1) } \\
\hline If I make a suggestion, I initiate and organise the implementation of the proposal & 0.84 \\
\hline I am the active assistant of the eldership & 0.84 \\
\hline I take responsibility for my suggested initiatives & 0.80 \\
\hline When I am invited to help, I always contribute & 0.79 \\
\hline \multicolumn{2}{|l|}{ Moderate level of participation (F2) } \\
\hline I advise and educate eldership employees on their performance & 0.64 \\
\hline $\begin{array}{l}\text { I discuss positive and negative aspects of eldership activities with other community } \\
\text { members and my neighbours }\end{array}$ & 0.56 \\
\hline \multicolumn{2}{|l|}{ Low level of participation (F3) } \\
\hline I demand high-quality services from the eldership & 0.55 \\
\hline I try to keep as distant contact with the eldership as possible & 0.44 \\
\hline
\end{tabular}

Interval scale was transformed into the rating scale. The attribute, expressing the highest level of the customers' participation, was selected as the base for the attribution of the participation activeness items to some appropriate participation level. According to a general assessment of variables, the percentage of participants in various participation levels can be identified. It was identified that $12.8 \%$ of respondents were attributed to the high level of participation, $64.7 \%$ - to the moderate, $22.5 \%$ - to the low level of participation. To identify what socio-demographic characteristics determine customer participation activeness (participation level), independent variables (age, education, place of living (city, rural areas), income level) were used for analysis. Statistically significant differences in groups of respondents with different socio-demographic characteristics (chi-square criteria $(\chi 2)$, Pearson formula) were found. The results show that moderate participation level is dominant in all age groups. Persons, older than 75 years, and those with a lower level of education do not demonstrate high-level participation. Also, city inhabitants more often show low-level participatory behaviour than those living in other places. More active (high-level 
participation) are people of 30-59 years, living in rural areas and those with higher income. The big part of customers with low education level demonstrate moderate participation level.

Those people, who do not belong to any non-governmental organisation (NGO) or those who are only formal members, usually demonstrate moderate participatory efforts; and the most active members of NGO are especially active participators in public services. The self-reporting research data indicates that the majority of customers quite positively rate their participatory behaviour. More than half declare being active assistants, taking up the responsibility for suggested initiatives and organising implementation of own suggestions. It allows speaking about relatively high cooperation between eldership and local citizens. There are not many people who see themselves as demanding or keeping as indirect contact with eldership as possible.

Table 2: Self-reported Participation in Public Services $(n=600)$

\begin{tabular}{|l|c|c|c|c|}
\hline \multicolumn{1}{|c|}{ Items } & $\begin{array}{c}\text { Surely } \\
\text { yes } \\
(\%)\end{array}$ & $\begin{array}{c}\text { Probably } \\
\text { yes } \\
(\%)\end{array}$ & $\begin{array}{c}\text { Probably } \\
\text { no } \\
(\%)\end{array}$ & $\begin{array}{c}\text { Surely } \\
\text { no } \\
(\%)\end{array}$ \\
\hline $\begin{array}{l}\text { If I make suggestions, I initiate (organize) } \\
\text { implementation of the suggestion* }\end{array}$ & $\begin{array}{c}51,1 \\
\text { If }\end{array}$ & 30,8 & 11,8 & 6,3 \\
\hline I am the active assistant of the eldership* & 22,7 & 34,0 & 19,0 & 12,3 \\
\hline I take responsibility for my suggested initiatives* & 35,2 & 29,1 & 21,7 & 14,0 \\
\hline When I am invited to help, I always contribute* & 11,3 & 18,8 & 35,2 & 34,7 \\
\hline $\begin{array}{l}\text { I advise and educate eldership employees on they're } \\
\text { performance }\end{array}$ & & & & \\
\hline $\begin{array}{l}\text { I discuss positive and negative sides of eldership activities } \\
\text { with other community members, my neighbours }\end{array}$ & 32,4 & 46,0 & 12,2 & 9,3 \\
\hline I demand high quality services from the eldership & 9,7 & 17,9 & 37,4 & 35,0 \\
\hline I try to keep as distant contact with the eldership as possible & 9,3 & 18,2 & 40,3 & 32,2 \\
\hline
\end{tabular}

High participation level indicators

Such positive results may be explained by the fact that active citizens with the participation experience were selected for the research. Also, it is possible to state that there are more people, who tend to contribute when invited than those who first take the initiative and responsibility. Results are interpreted as hiding some appropriate complexity of relations between the provider and the customer. People feel obliged to respond to (the similar) behaviour or actions when they get the benefit and are encouraged to do so. It confirms the fact that customer participation is an issue to be managed (engagement platforms that foster interactions created, the right people need to be identified, selected, educated, and motivated).

\section{Conclusions}

Customer participation in public services supposes active customer effort, when personal resources are provided for service development. Customer participation can vary from the participatory behaviour that is needed for service delivery to the co-creation, where customer and service providers' efforts bring the mutually beneficial outcome. Four categories of participating customers in public services administered by Lithuanian elderships were identified in terms of the extent of customer input and contribution: "proactive" (clients who offer solutions and contribute when implementing them; "silent supporters" (clients that have positive attitude towards participation, but are reserved in taking the first step); "self-interested" (clients, who make some contributions when personal benefits are evident) "demanders" (clients, who interact with public crevice provider, usually on a claim or request basis). The survey with active Lithuanian eldership customers confirmed the three - level (low, moderate and high) customer participation model. The high level of participation is characterised by the following customer attitude and participatory behaviour: taking at least the part of the responsibility for failures in services; giving own resources (time, mental, emotional, 
Damkuviene et al., Adv. J Social Sci.; Vol. 2 Issue 1, pp: 40-47, May 2018

physical); consciously seeking for the quality of service; helping other customers, providing suggestions for service improvement.

Analysis of participatory customer behaviour in the light of socio-demographic parameters shows that people, belonging to the age group of 30-59 years, living in rural localities (not city centre), and those with higher income level, are the most active participants. Customer participatory behaviour is not always selfemergent. Public service providers need to pay conscious attention to how they identify, select, educate, motivate customers to participate in public services so that mutually beneficial changes occur.

\section{How to Cite this Article:}

Damkuviene, M., \& Petukiene, E. (2018, April 15). Co-Creation of Public Services; Levels of Customers' Participation. Advanced Journal of Social Science, 2(1), 40-47. doi: 10.21467/ajss.2.1.40-47

\section{References}

Alford, J. (2009). Engaging Public Sector Clients. From Service-Delivery to Co-production. London: Palgrave MacMillan.

Arnstein, S. R. (1969). A Ladder of Citizen Participation. Journal of the American Institute of Planners, 35(4), 216-224.

Arnould, E. J., Price, L. L., Malshe, A. (2006). Toward a Cultural Resource-Based Theory of the Consumer. In Lusch R. F., Vargo S. L. (Ed.), The service-dominant logic of marketing: Dialog, Debate, and Directions (p.p. 91-104). New York: M. S. Sharpe.

Bitner, M.J., Faranda, W.T., Hubbert, A.R. \& Zeitham, V.A. (1997). Customer Contributions and Roles in Service Delivery. International Journal of Service Industry Management, 8(3), 193-205.

Claycomb, C., Lengnick-Hall, C. A., Inks, L. W. (2001). The Customer as a Productive Resource: a Pilot Study and Strategic Implications. Journal of Business Strategies, 18, 47-69.

Durose, C., Needham, C., Mangan, C. \& Rees, J. (2015). Generating 'good enough' evidence for coproduction. Evidence and Policy, 1-17. Etgar, M. A (2008). Descriptive Model of the Consumer Co-production Process. Journal of the Academy of Marketing Science, 36, 97-108. Francis Gouillart \& Tina Hallett (2015). Co-Creation in Government. Stanford social innovation review, 13(2), 40-47.

Grissemann, U. S., Stokburger-Sauer N. E. (2012). Customer co-creation of travel services: The role of company support and customer satisfaction with the co-creation performance. Tourism Management, 33, 1483-1492.

Harris, K., Baron, S. \& Davies, B. (1999). What sort of soil do rhododendrons like?-comparing customer and employee responses to requests for product-related information. The Journal of Services Marketing, 13(1), 21-37.

Harris, K., Baron, S. \& Ratcliffe, J. (1995). Customers as oral participants in a service setting. Journal of Services Marketing, 9(4), 64-76.

Hoyer, W.D., Chandy, R., Dorotic, M., Krafft, M., Singh, S. S (2010). Consumer Cocreation in New Product Development. Journal of Service Research, 13(3), 283-296.

Hsieh, A. T., Yen, C. H, Chin, K. C. (2004). Participative Customers as Partial Employees and Service Provider Workload. International Journal of Service Industry Management, 15(2), 187-199.

Jacob, F., Rettinger, B. (2010). The Role of customer co-production in value creation. Proceedings of the Naples Forum on Service.

John, J. D. (2003). The Effects of Employee Service Quality Provision and Customer Personality Traits on Customer Participation, Satisfaction, and Repurchase Intentions. Doctoral Dissertation, Louisiana State University.

Joshi, A., Moore, M. (2004). Institutionalised Co-production: Unorthodox Public Service Delivery in Challenging Environments. Journal of Development Studies, 40(4), 31-49.

Kelley, S., James, H. \& Steven, S. (1990). Customer participation in service production and delivery. Journal of Retailing, 66(3), 315-335.

Kinard, B. R., Capella, M. L. (2006). Relationship marketing: the influence of consumer involvement on perceived service benefits. Journal of Services Marketing, 20(6/7), 359-368.

Kreiken, W. (2008). Eight levels of public participation. In Coastal Wiki. Retrieved October 1, 2017.

Lusch, R. F., Vargo, S. L. (2006). Service-dominant logic as foundation for the general theory. In Lusch R. F., Vargo S. L. (Ed.), The servicedominant logic of marketing: Dialog, Debate, and Directions (p.p. 406-420) New York: M. E. Sharpe.

Mottiar, Sh., White, F. (2003). Co-production as a Form of Service Delivery: Community Policing in Alexandra Township.

Needham, C., Carr, S. (2009). Co-production: an Emerging Evidence Base for Adult Social Care Transformation. Research Briefing 31. London: Social Care Institution for Excellence.

O’Hern, M. S. \& Rindfleisch, A. (2009). Customer Co-Creation: A Typology and Research Agenda. Review of Marketing Research, 6, 84106.

Osborne, S. P. Radnor, Z., Strokosch, K. (2016). Co-production and the co-creation of value in public services: a suitable case for treatment? Public Management Review, 18(5), 639-653.

Parker, C. \& Ward, P. (2000). An analysis of role adoptions and scripts during customer-to-customer encounters. European Journal of Marketing, 34(3/4), 241-358.

Prahalad, C. K., Ramaswamy, V. (2000). Co-opting Customer Competence. Harvard Business Review, 78(1), 79-87.

Prahalad, C. K., Ramaswamy, V. (2004). Co-creating unique value with customers. Strategy \& Leadership, 32(3), 4-9.

Rodie, A. R., Kleine, S. S. (2000). Customer Participation in Services Production and Delivery. In T. A. Swartz and D. Iacobucci (Eds.), Handbook of Services Marketing and Management (p.p. 111-125). Beverley Hills, California: Sage Publications.

Sampson, S. E., Froehle C.M. (2006). Foundations and Implications of a Proposed Unified Services Theory. Production and Operations Management, 15(2), 329 - 343.

Stembert, N. (2011). Participations and co-creation in Public Domain. Master Thesis Design for Interaction Industrial Design Engineering.

Vargo, S. L., Lusch, R. F. (2004). Evolving to a New Dominant Logic for Marketing. Journal of Marketing, 68, 1-17. 
Co-Creation of Public Services; Levels of Customers' Participation

Voorberg, W. H., Bekkers' V. J. J. M. \& Tummers, L. G. (2015). A Systematic Review of Co-Creation and Co-Production: Embarking on the social innovation journey. Public Management Review, 17(9), 1333-1357.

Yen, H.R., Gwinner, K.P., Su, W. (2004). The Impact of Customer Participation and Service Expectation on Locus Attributions Following Service Failure. International Journal of Service Industry Management, 15(1), 7-26.

Publish your research article in AIJR journals-

$\checkmark$ Online Submission and Tracking

$\checkmark$ Peer-Reviewed

$\checkmark$ Rapid decision

$\checkmark \quad$ Immediate Publication after acceptance

$\checkmark \quad$ Articles freely available online

$\checkmark$ Retain full copyright of your article.

Submit your article at journals.aijr.in
Publish your books with AIJR publisher-

$\checkmark \quad$ Publish with ISBN and DOI.

$\checkmark$ Publish Thesis/Dissertation as Monograph.

$\checkmark$ Publish Book Monograph.

$\checkmark$ Publish Edited Volume/ Book.

$\checkmark$ Publish Conference Proceedings

$\checkmark \quad$ Retain full copyright of your books.

Submit your manuscript at books.aijr.org 